\title{
Cranial and spinal injuries in motorcycle accidents: A hospital-based study
}

\author{
(1) Çağatay Özdöl, M.D., ${ }^{1}$ ๑ Tolga Gediz, M.D., ${ }^{1} \odot$ Kamran Aghayev, M.D. ${ }^{2}$
}

${ }^{1}$ Department of Neurosurgery, Antalya Training and Research Hospital, Antalya-Turkey

${ }^{2}$ Department of Neurosurgery, Biruni University Faculty of Medicine, İstanbul-Turkey

\begin{abstract}
BACKGROUND: Injuries caused by motorcycle accidents have been reported in several studies with an examination from a general trauma point of view. However, to our knowledge, there is no detailed study specific to central nervous system injuries. This research was focused on central nervous system injuries associated with motorcycle accidents.

METHODS: The medical records of 540 patients who were admitted to the emergency department between 2008 and 2016 as the result of a motorcycle accident were retrospectively evaluated. Data were collected from electronic medical records, follow-up forms, and radiological images. Information on patient age, gender, type and site of injury, helmet use, alcohol level, Glasgow Coma Scale score on admission, length of stay in the intensive care unit and hospital, neurological status on discharge, and follow-up was collected and analyzed.

RESULTS: A total of 486 of 540 patients (90\%) were male, 54 (10\%) were female, and the mean age was $31 \pm 18$ years (range: $2-85$ years, median: 25 years). Cranial injuries were detected in 320 cases (59\%). The distribution of cranial injuries was: epidural hemorrhage (12.6\%), subdural hemorrhage (15.2\%), depressed fracture $(10.4 \%)$, linear fracture $(23 \%)$, skull base fracture $(5.5 \%)$, diffuse axonal injury $(9.3 \%)$, subarachnoid hemorrhage $(25.2 \%)$, intracerebral hemorrhage (13.5\%), and contusion (26.3\%). Spinal fractures were detected in 52 cases (9.6\%). Twenty-two (4.07\%) of the spinal fractures were observed in the cervical region, 10 (1.85\%) in the thoracic region, and $20(3.7 \%)$ in the lumbar region. The mean length of stay in the hospital was $8.2 \pm 4$ days and 7 days in the intensive care unit. Sixty-eight patients (12.6\%) died. Traumatic cranial entities other than linear fracture were associated with an elevated level of mortality. A Glasgow Coma Scale score of 6 or less was associated with significant mortality (68\%).
\end{abstract}

CONCLUSION: A detailed report of motorcycle accident-associated central nervous system injuries is provided. The use of protective equipment, such as helmets, significantly reduced the rate of cerebral injury and death.

Keywords: Accident; head trauma; motorcycle; spine trauma; trauma.

\section{INTRODUCTION}

In developing countries, motorcycles are the preferred means of transportation. Because of their low cost, cheap maintenance, and easy handling, their use is increasing. Also, from public point of view, there are several advantages such as decreased traffic crowding and air pollution. Motorcycle accidents are on rise, ${ }^{[1]}$ and are associated with significant health threats. These accidents lead to more severe injuries in comparison to those caused by other vehicles because of dif- ferences in protective equipment and mechanisms of injury. Motorcycle drivers are exposed to 20-fold increased risk of injury and death per kilometer. ${ }^{[2]}$ According to National Highway Traffic Safety Administration report, motorcycle drivers have 8-fold increased risk of injury and 35-fold increased risk of death. ${ }^{[3]}$ It was estimated that although motorcycle accidents contribute to $1 \%$ of all traffic accidents, they lead to $14 \%$ of all deaths. ${ }^{[4]}$ A multinational study has shown that morbidity associated with motorcycle injuries is twice as high in low- and middle-income countries in comparison with that

Cite this article as: Özdöl Ç, Gediz T, Aghayev K. Cranial and spinal injuries in motorcycle accidents: A hospital-based study. Ulus Travma Acil Cerrahi Derg 2019;25:167-171.

Address for correspondence: Çağatay Özdöl, M.D.

Antalya Eğitim ve Araştırma Hastanesi, Nöroşirürji Kliniği, 07100 Antalya, Turkey.

Tel: +90 242 - 2494400 E-mail: drcagatayozdol@gmail.com

Ulus Travma Acil Cerrahi Derg 2019;25(2):167-17I DOI: 10.14744/tjtes.2019.46II6 Submitted: 02.09.2018 Accepted: 06.02.2019 Online: I4.03.2019

Copyright 2019 Turkish Association of Trauma and Emergency Surgery 
in high-income countries, ${ }^{[5]}$ making them an important issue in developing countries.

Most of the studies regarding motorcycle injuries are focused on general aspects of trauma. ${ }^{[6-10]}$ However, there is not much information regarding details of brain and spine injuries. This study aimed to report neurosurgical injuries associated with motorcycle accidents in a large tertiary hospital.

\section{MATERIALS AND METHODS}

This study was approved by the Antalya Training and Research Hospital ethics committee (decision dated 08/03/2018 and numbered 5/9). A total of 540 patients who were admitted to Antalya Training and Research Hospital after motorcycle accidents and were consulted by neurosurgical team between November 2008 and December 2016 were retrospectively analyzed using hospital information system (Sarus HBYS) and radiographic imaging system (Sectra PACS). Other motor vehicle and bicycle accident victims were excluded from this study. We collected data regarding age, sex, use of helmet, presence of alcohol, admission Glasgow Coma Score (GCS), trauma characteristics, surgical interventions, length of stay in ICU and hospital, and radiological data. From neurosurgical point of view, brain injuries were classified into following categories: linear fracture, fissure, depressed fracture, skull base fracture, maxillofacial fractures, subarachnoid hemorrhage, epidural hematoma, subdural hematoma, intracerebral hematoma, diffuse axonal injury, and contusion. Spinal injuries were classified according to the location-cervical, thoracic, lumbar; and type of trauma-compression, burst, dislocation.

Statistical analysis was performed by using the SPSS (Statistical Package for Social Sciences) software. The Mann-Whitney $U$ test and chi-square tests were employed for statistical analysis. $\mathrm{P}$ value less than 0.05 was considered statistically significant.

\section{RESULTS}

Of these 540 cases, 486 were males (90\%) and 54 were females (10\%). The mean age was $31 \pm 18$ years (distribution $2-85$ ). The majority of accident victims were males aged I I-20 years (Fig. I). The majority of accidents took place in June-August (32\%), followed by March-May (26\%), September-November (24\%), and December-February (18\%) (Fig. 2). Of all the injuries, $65.2 \%$ happened when the driver did not use a helmet; in $28.7 \%$ cases, the driver's blood had traces of alcohol. The majority of injuries were head (59\%) and musculoskeletal (51\%) trauma. The distribution of head injuries according to the type of injury is presented in Table I. Among the patients presenting with head trauma, 352 had no helmets, and 188 had helmets $(p<0.00 \mathrm{I})$. GCS on admission varied from 3 to 15 , mean was 12 \pm 4 , median 14. Mean GCS in patients wearing a helmet was 13, and in those without a helmet was 6 $(p=0.0007)$. Head injuries were present in 320 cases $(59 \%)$.

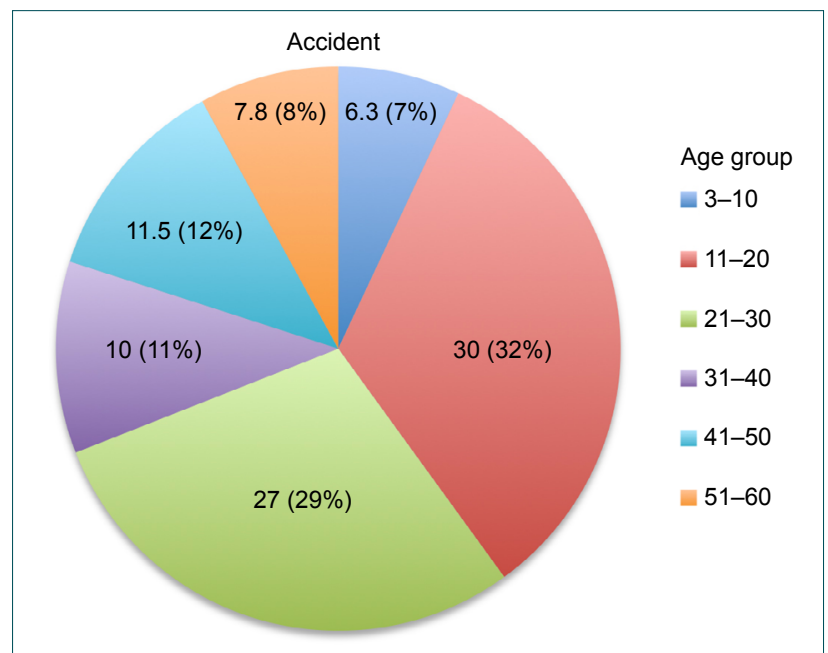

Figure 1. The distribution pattern of motorcycle accidents by age group.

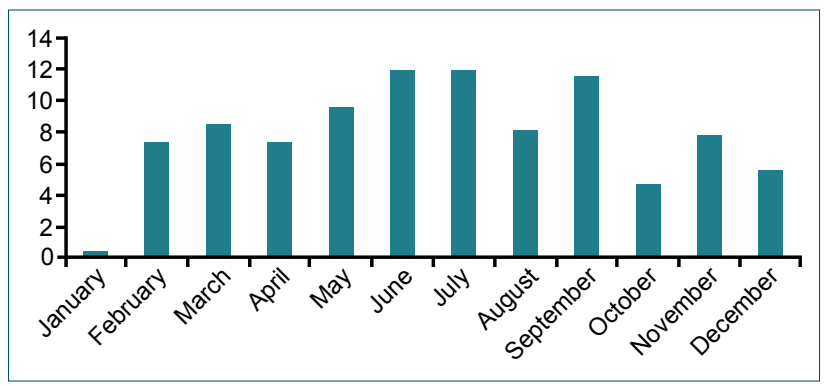

Figure 2. The distribution of motorcycle accidents by month.

The distribution of spine injuries is summarized in Table 2. There was no statistically significant difference regarding cervical spine injuries between patients with and without a helmet $(p=0.197)$. Extremity injuries were present in 102 cases (19\%); 65 cases (12\%) had both extremity and head injuries; 42 cases $(7.7 \%)$ had chest injuries; and 14 cases $(2.6 \%)$ had abdominal injuries. Neither spinal nor extremity injuries were associated with mortality.

The mean hospital stay duration was $8.2 \pm 4$ days. In patients admitted to ICU, the mean stay was 7 days. In total, I 77 (32.7\%) patients were operated, and 185 surgeries were performed. There were 50 epidural hematomas, 52 subdural hematomas, 7 intracerebral hematomas, 34 depressed fractures, 2 contusions, 10 cervical spine fractures, 7 thoracic spine fractures, and 15 lumbar spine fracture cases. Out of 306 patients who were initially followed conservatively, 10 were operated (6 subdural hematomas, 2 intracerebral hematomas, 2 epidural hematomas). The total mortality rate was $12.6 \%$ (68 patients); men had higher rate (66 out of $486,14 \%$ ) than women ( 2 out of $54,3.7 \%$ ), and the difference reached statistical significance $(p=0.048)$. GCS less or equal to 6 was associated with significant mortality (68\%). The mortality rate among patients with GCS more than 6 was $1.8 \%$. The statistical difference between the two groups reached the significance level $p<0.0001$. The mortality rate was $29 \%$ in operated group and $1.8 \%$ in conser- 
Table I. The distribution of head traumas according to the type of injury

\begin{tabular}{lcc}
\hline & $\mathbf{n}$ & $\%$ \\
\hline Epidural hemorrhage & 68 & 12.6 \\
Subdural hemorrhage & 82 & 15.2 \\
Depressed fracture & 56 & 10.4 \\
Linear fracture & 124 & 23 \\
Skull base fracture & 30 & 5.5 \\
Diffuse axonal injury & 50 & 9.3 \\
Subarachnoid hemorrhage & 136 & 25.2 \\
Intracerebral hemorrhage & 73 & 13.5 \\
Contusion & 142 & 26.3 \\
Maxillofacial injuries & 72 & 13.3 \\
Epidural + subdural hemorrhage & 26 & 4.8 \\
Epidural hemorrhage + linear fracture & 20 & 3.7 \\
Epidural hemorrhage + depressed fracture & 32 & 6 \\
Subdural hemorrhage + linear fracture & 10 & 1.9 \\
Subdural hemorrhage + depressed fracture & 26 & 4.8 \\
\hline
\end{tabular}

Table 2. The distribution of spine injuries

\begin{tabular}{ccc}
\hline & $\mathbf{n}$ & $\%$ \\
\hline Cervical spine fracture & 22 & 4.07 \\
Atlanto-axial & 10 & \\
C5 & 5 & \\
C6 & 7 & \\
Thoracic spine fracture & 10 & 1.85 \\
T 8 & 1 & \\
TII & 5 & \\
T12 & 4 & \\
Lumbar spine fracture & 20 & 3.7 \\
LI & 13 & \\
L2 & 7 & \\
\hline
\end{tabular}

vative group, $\mathrm{p}<0.01$. Although extremity, spinal, maxillofacial, and abdominal trauma did not contribute to mortality, the mortality rate was $29 \%$ in patients with thoracic trauma and I I \% without $(p=0.022)$.

When head injury was present, the mortality rate was $19.4 \%$; and it was $2.7 \%$ without head injury $(p<0.001)$. Except for linear fracture, all other traumatic entities were associated with elevated level of mortality: epidural hematoma $26 \%$ $(p=0.009)$, subdural hematoma $32 \%(p<0.0001)$, depressed fracture $32 \%(p=0.00 I)$, diffuse axonal injury $48 \%(p<0.0001)$, subarachnoid hemorrhage $35 \%(p<0.0001)$, and cerebral contusion $24 \%(p=0.0001)$.

\section{DISCUSSION}

The comprehensive management of trauma patients is complex, and it should be performed at specialized centers. Since the vast majority of these patients present with multiple injuries, multidisciplinary approach is absolute prerequisite to maintain the quality of care. The most common mode of transportation in our country is by road. Hence, traffic accidents have become a major cause of injury and death. The number of people riding motorcycle is significant in areas with warm climate, like Antalya. Motorcycle accidents have several specific nuances that distinguish them from the rest of traffic accidents. Since the lack of effective protection like in the car, the bodily injuries tend to be more frequent and severe. Studies have shown that the motorcycle usage is more among young male population..$^{[6,11-14]}$ Thus, accidents affect the most active section of the society, and result in significant public health problem. Numerous papers were published regarding the nervous system injuries in motor vehicle accidents, yet a very small fraction of them was dedicated to motorcycle accidents. Therefore, demonstrating the risk factors contributing to death and permanent injury is of paramount importance. Gorski et al. ${ }^{[6]}$ have found head trauma in $33 \%$ of patients and spinal injury in $14 \%$ of patients in motocross races, and they reported low overall morbidity but high mortality which was related to the cases requiring surgery. Several studies have shown that head, thorax, and abdominal injuries are major contributors of mortality. ${ }^{[15-17]}$ Similarly, in our study the largest injury group among fatal injuries (12.6\%) was thoracic trauma followed by head trauma.

In accordance with the literature reports, our study confirmed that the majority of patients admitted with motorcycle accidents were young males, and the majority of neurosurgical injuries were head traumas (59\%). Head trauma is the most important cause of mortality, ${ }^{[18,19]}$ and our study also showed that when present, it significantly affects the mortality $(19.4 \%$ vs $2.7 \%, \mathrm{p}<0.00 \mathrm{I})$. Another important aspect is the presence of intracranial pathology like various forms of hemorrhage, depressed skull fracture, contusion, and diffuse axonal injury. These entities were associated with increased mortality yet linear fracture alone was not. This fact clearly shows that the brain (not head) injury is the most important factor contributing to mortality.

Wearing a helmet has proven to reduce the severity and associated mortality of head injuries. ${ }^{[20-25]}$ Similarly, in our series the rate $(352$ vs $188, p<0.001)$ and the severity (mean GCS 13 vs $6, p=0.0007$ ) of head injury was high when helmet was not used. Despite the clarity regarding the protective role of helmet for head injuries, disagreements exist when it comes to cervical spine. The beneficial effect is so negligible that some studies failed to fully demonstrate it. For example, Khor et al., ${ }^{[26]}$ in their recent large study, observed only $1 \%$ decrease in cervical spine injuries in patients wearing a helmet. Some authors even argued that wearing helmet might 
actually increase the rate and severity of cervical injuries, yet further studies showed no such effect. ${ }^{[27-29]}$ In our study, there was no statistically significant difference between the helmet-wearers and non-helmet-wearers regarding cervical spine injury $(p=0.197)$. This might be because of type 2 error as the protective effect is too little to be observed in a small cohort. The number of cervical fractures was high in our study, yet the lower thoracic region and upper lumbar region of vertebral column were most frequently affected. This was one of the most important findings of this study because currently there is no effective protection for this area of the spine in motorcycle riders.

\section{Limitations}

This study has certain limitations. First, study data reflect admissions at a tertiary hospital. Data from other hospitals were not available. Moreover, these data may show variability in the regions that are socioeconomically and geographically different. Comprehensive investigations taking into consideration data from all hospitals in the same region will be useful in this regard. Another limitation is that the research was retrospectively conducted.

\section{Conclusion}

High rate of head and spine injuries has been detected in motorcycle accidents, and detailed distribution of various type of pathologies has been reported. The protective role of helmet wearing has been demonstrated for brain injury but not for cervical spine injuries. Mortality is significantly associated with brain injury (except linear fractures), admission GKS, and presence of thoracic trauma. Evaluation of the patients who presented with motorcycle accident primarily for brain and thoracic trauma is one of the most important factors that increase the probability of survival of patients.

Conflict of interest: None declared.

\section{REFERENCES}

1. Bambach MR, Mitchell RJ. The rising burden of serious thoracic trauma sustained by motorcyclists in road traffic crashes. Accid Anal Prev 2014;62:248-58. [CrossRef]

2. Solagberu BA, Ofoegbu CK, Nasir AA, Ogundipe OK, Adekanye AO, Abdur-Rahman LO. Motorcycle injuries in a developing country and the vulnerability of riders, passengers, and pedestrians. Inj Prev 2006;12:266-8. [CrossRef]

3. United States. National Highway Traffic Safety Administration, University of North Carolina (System). Highway Safety Research Center. Countermeasures that work a highway safety countermeasure guide for state highway safety offices. 4th ed. Washington, D.C.: U.S. National Highway Traffic Safety Administration; 2009. 1 online resource (301 p.) ill.

4. Clarke DD, Ward P, Bartle C, Truman W. The role of motorcyclist and other driver behaviour in two types of serious accident in the UK. Accid Anal Prev 2007;39:974-81. [CrossRef]

5. De Silva MJ, Roberts I, Perel P, Edwards P, Kenward MG, Fernandes J, et al; CRASH Trial Collaborators. Patient outcome after traumatic brain injury in high-, middle- and low-income countries: analysis of data on 8927 patients in 46 countries. Int J Epidemiol 2009;38:452-8. [CrossRef]

6. Gorski TF, Gorski YC, McLeod G, Suh D, Cordero R, Essien F, et al. Patterns of injury and outcomes associated with motocross accidents. Am Surg 2003;69:895-8.

7. Gorios C, Armond Jde E, Rodrigues CL, Pernambuco H, Iporre RO, Colombo-Souza P. Analysis of hospitalization occurred due to motorcycles accidents in São Paulo city. Acta Ortop Bras 2015;23:212-4.

8. Gupta A, Jaipuria J, Bagdia A, Kumar S, Sagar S, Misra MC. Motorised two-wheeler crash and helmets: injury patterns, severity, mortality and the consequence of gender bias. World J Surg 2014;38:215-21. [CrossRef]

9. Ozkan S, Kiliç S, Durukan P, Akdur O, Vardar A, Geyik S, et al. Occupational injuries admitted to the Emergency Department. Ulus Travma Acil Cerrahi Derg 2010;16:241-7.

10. Zettas JP, Zettas P, Thanasophon B. Injury patterns in motorcycle accidents. J Trauma 1979;19:833-6. [CrossRef]

11. Lin MR, Kraus JF. A review of risk factors and patterns of motorcycle injuries. Accid Anal Prev 2009;41:710-22. [CrossRef]

12. Leong QM, Tsung Shyen KG, Appasamy V, Chiu MT. Young adults and riding position: factors that affect mortality among inpatient adult motorcycle casualties: a major trauma center experience. World J Surg 2009;33:870-3. [CrossRef]

13. Murphy RK, McEvoy L, Kelleher MO, Bolger C, Phillips J. The burden of motorcycle-related neuro-trauma in Ireland and associated helmet usage. Br J Neurosurg 2009;23:162-4. [CrossRef]

14. Coben JH, Steiner CA, Owens P. Motorcycle-related hospitalizations in the United States, 2001. Am J Prev Med 2004;27:355-62. [CrossRef]

15. Silva LOJE, Fernanda Bellolio M, Smith EM, Daniels DJ, Lohse CM, Campbell RL. Motocross-associated head and spine injuries in adult patients evaluatedin an emergency department. Am J Emerg Med 2017;35:1485-9. [CrossRef]

16. Doyle D, Muir M, Chinn B. Motorcycle accidents in Strathclyde Region, Scotland during 1992: a study of the injuries sustained. Health Bull (Edinb) 1995;53:386-94.

17. Ankarath S, Giannoudis PV, Barlow I, Bellamy MC, Matthews SJ, Smith RM. Injury patterns associated with mortality following motorcycle crashes. Injury 2002;33:473-7. [CrossRef]

18. Ji M, Gilchick RA, Bender SJ. Trends in helmet use and head injuries in San Diego County: the effect of bicycle helmet legislation. Accid Anal Prev 2006;38:128-34. [CrossRef]

19. Keng SH. Helmet use and motorcycle fatalities in Taiwan. Accid Anal Prev 2005;37:349-55. [CrossRef]

20. Auman KM, Kufera JA, Ballesteros MF, Smialek JE, Dischinger PC. Autopsy study of motorcyclist fatalities: the effect of the 1992 Maryland motorcycle helmet use law. Am J Public Health 2002;92:1352-5. [CrossRef]

21. Sauter C, Zhu S, Allen S, Hargarten S, Layde PM. Increased risk of death or disability in unhelmeted Wisconsin motorcyclists. WMJ 2005;104:39-44.

22. Hundley JC, Kilgo PD, Miller PR, Chang MC, Hensberry RA, Meredith JW, et al. Non-helmeted motorcyclists: a burden to society? A study using the National Trauma Data Bank. J Trauma 2004;57:944-9. [CrossRef]

23. Peeters S, Blaine C, Vycheth I, Nang S, Vuthy D, Park KB. Epidemiology of Traumatic Brain Injuries at a Major Government Hospitalin Cambodia. World Neurosurg 2017;97:580-9. [CrossRef]

24. Lateef F. Riding motorcycles: is it a lower limb hazard? Singapore Med J 2002;43:566-9.

25. Eastridge BJ, Shafi S, Minei JP, Culica D, McConnel C, Gentilello L. Economic impact of motorcycle helmets: from impact to discharge. J Trauma 2006;60:978-83. [CrossRef] 
26. Khor D, Inaba K, Aiolfi A, Delapena S, Benjamin E, Matsushima K, et al. The impact of helmet use on outcomes after a motorcycle crash. Injury 2017;48:1093-7. [CrossRef]

27. Page PS, Wei Z, Brooks NP. Motorcycle helmets and cervical spine injuries: a 5-year experience at a Level 1 trauma center. J Neurosurg Spine 2018;28:607-11. [CrossRef]
28. Hooten KG, Murad GJ. Helmet use and cervical spine injury: a review of motorcycle, moped, and bicycle accidents at a level 1 trauma center. J Neurotrauma 2014;31:1329-33. [CrossRef]

29. Ooi SS, Wong SV, Yeap JS, Umar R. Relationship between cervical spine injury and helmet use in motorcycle road crashes. Asia Pac J Public Health 2011;23:608-19. [CrossRef]

\section{ORİJINAL ÇALIŞMA - ÖZET}

\section{Motosiklet kazalarında kafa ve omurga yaralanmaları: Hastane tabanlı bir çalışma Dr. Cağatay Özdöl, ${ }^{1}$ Dr. Tolga Gediz, ${ }^{1}$ Dr. Kamran Aghayev ${ }^{2}$}

${ }^{1}$ Antalya Eğitim ve Araştırma Hastanesi, Nöroşirürji Kliniği, Antalya

${ }^{2}$ Biruni Üniversitesi Tıp Fakültesi, Nöroşirürji Kliniği, İstanbul

AMAÇ: Motosiklet kazalarına bağlı yaralanmalar, genel travma açısından çeşitli çalışmalarda incelenmiştir. Bununla birlikte, merkezi sinir sistemi yaralanmalarına ilişkin ayrıntılı bir çalışma yoktur. Bu çalışma motosiklet kazaları ile ilişkili merkezi sinir sistemi yaralanmalarına odaklanmışır.

GEREÇ VE YÖNTEM: 2008 ile 2016 yılları arasında motosiklet kazası nedeniyle acil servise başvuran 540 hastanın tıbbi kayıtları geriye dönük olarak değerlendirildi. Veriler elektronik tıbbi kayıtlardan, takip formlarından ve radyolojik görüntülerden elde edildi. Hastaların yaşı, cinsiyeti, yaralanma tipi ve yeri, kask kullanımı, alkol düzeyleri, Glasgow Koma Skorları, yoğun bakım ünitesinde kalış süreleri, taburcu olurken ve takiplerde nörolojik durumları gibi bilgiler toplanmıştır.

BULGULAR: Çalışmaya alınan 540 olgunun 486’sı (\%90) erkek, 54'ü (\%।0) kadın, yaş ortalaması 3I \pm I8 (dağıım 2-85, medyan 25) idi. Kraniyal yaralanmalar 320 olguda (\%59) saptandı. Kraniyal yaralanmaların dağıımı şöyledir: Epidural kanama (\%।2.6), subdural hemoraji (\%।5.2), deprese kırık (\%।0.4), lineer kırık (\%23), kafa tabanı kırığı (\%5.5), diffüz aksonal yaralanma (\%9.3), subaraknoid kanama (\%25.2), intraserebral hemoraji (\%।3.5), kontüzyon (\%26.3). Spinal kırıklar 52 olguda (\%9.6) tespit edildi. Servikal bölgede 22 (\%4.07) omurga kırı̆ı, torasik bölgede 10 (\%।.85) ve lomber bölgede 20 (\%3.7) gözlendi. Hastanede kalış süresi yoğun bakımda ortalama $8.2 \pm 4$ gün, ortalama yedi gündü. Altmış sekiz hasta (\%।2.6) hayatını kaybetti. Lineer kırık hariç diğer tüm kraniyal yaralanmalar yüksek mortalite ile ilşkiliydi. Ayrıca, 6 veya daha düşük Glasgow Koma Skorları, önemli mortalite (\%68) ile ilişkilendirildi.

TARTIŞMA: Motosiklet kazalarının neden olduğu merkezi sinir sistemi yaralanmalarının ayrıntılı bir raporu verilmiştir. Kask gibi koruyucu ekipmanların kullanılması, beyin hasarı ve ölüm oranını önemli ölçüde azaltır.

Anahtar sözcükler: Kafa travması; kaza; motosiklet; spinal travma; travma.

Ulus Travma Acil Cerrahi Derg 2019;25(2):167-171 doi: 10.14744/tjtes.2019.46।16 